\title{
An Investigation of 8th Grade Students' Knowledge on Geometrical Objects in Terms of Van Heile Levels of Understanding Geometry
}

\author{
Fatih Karapınar ${ }^{1}$, Onur Alp İlhan ${ }^{2, *}$ \\ ${ }^{1}$ Erciyes University, Educational Sciences Institute, Mathematics Education \\ ${ }^{2}$ Erciyes University, Faculty of Education, Department of Mathematics and Science Education, Department of Mathematics Education \\ *Corresponding author: oailhan@erciyes.edu.tr
}

\begin{abstract}
In this study, it was aimed to determine 8th grade students' Van Hiele levels of understanding geometry and to examine their knowledge on geometric objects in terms of Van Hiele levels of understanding geometry. Survey model, a quantitative research design was used in the research. The study group consists of 161 students from three different schools of National Ministry of Education located in the districts of Melikgazi and Kocasinan in Kayseri province. The Van Hiele Geometry Test and the Geometric objects Achievement Test developed by the researcher was used to collect the data of the study. Some of the results obtained from the research are as follows: The Van Hiele levels of understanding geometry of the students who participated in the research were found to be lower compared to what they are expected to have at the present. There was a high correlation between the scores of the students on both tests. Significant mean differences were found among the schools in terms of both the Van Hiele Geometry Test and the Geometric Objects Achievement Test. When the data were analyzed by gender variable, there were significant differences in favor of girl students for both tests.
\end{abstract}

Keywords: Van Hiele, geometric objects, geometric thinking, geometry, 8th grades

Cite This Article: Fatih Karapınar, and Onur Alp İlhan, “An Investigation of 8th Grade Students' Knowledge on Geometrical Objects in Terms of Van Heile Levels of Understanding Geometry." American Journal of Educational Research, vol. 6, no. 2 (2018): 96-103. doi: 10.12691/education-6-2-1.

\section{Introduction}

Mathematics has always been a guide in the history of humanity. As a result of development and progress of mathematics, science has advanced, science has accelerated technological developments, people's peace and prosperity levels have increased, their lifestyles have changed, and life expectencies has changed. People have overcome the difficulties they encountered in their lives through mathematics and have been guided their lives by mathematics.

Many scientists have made different definitions from the past to the present day about mathematics, which has the power to change human life, knowledge, societies and technology. In [1] defined mathematics ${ }^{1}$ as is a science that contributes to the development of talents and skills, helping people to free and objective thinking, increasing self-esteem, explaining the causes and consequences of living problems. For this reason, mathematics allows people to think freely in their lives. It enables them to overcome the difficulties they encounter and their life problems using their abilities. Mathematics

\footnotetext{
${ }^{1}$ This work was supported by Erciyes University Scientific Research Projects Unit (project code :SYL-2016-6679)
}

improves people's knowledge and skills and gives them confidence. Through mathematics, people are developing their self-confidence, developing objective and critical thinking skills, systematically and correctly thinking about problems in life, and establishing cause-effect relationships [2].

Mathematics is not just a discipline that made from shapes and symbols, from rules to operations. It is a network that has a meaningful integrity in it, a certain order, and a strong relationship. In addition, there is a strong relationship between mathematics and other disciplines, with other disciplines and everyday life. In this context, associative skill is a skill that allows a mathematical concept to relate to everyday life or mathematical concepts among themselves [3] (Ministry of National Education (MNE), 2013).

Mathematics has important subject areas universally. National Association of Teachers of Mathematics (NCTM) emphasized that geometry is one of the most important and fundamental subject areas of mathematics and one of the conceptual building blocks [4] (NCTM, 2000). When we plan our daily life, we need geometry that exists in many stages of our daily life as we need mathematics when we make calculations about our life, from our home where we live, up to our mobile phone that we use.

Geometry is a field of objects and shapes that have a very important place in human life. We often encounter 
these concepts in our everyday lives. We have a specific pattern, style and geometric shape that we use in our daily lives. The reason for this is to ensure that the match is handy and that it does the job best suited to it. This adds an aesthetic stance and value to the material. We use geometry as a resource so that we can solve many problems that arise in our daily life in the form of painting a wall in a similar way, framing [5].

Olkun and Aydogdu [6] stated that geometry should not be considered as an important subject area and conceptual building block of mathematics only. Geometry helps students to relate geometric structures with other sub-areas of mathematics they encounter in their environment and solve problems that they encounter in their daily lives through relationships they build. Geometric thinking is not only a sub-learning area of mathematics, but it is also related to all other courses and contributes to the development of many cognitive and mental skills of students. We can divide the basic aims of geometry into two [7] :

1. to offer the ability of explaining the students' environment, it's physical world, and understand the universe

2. to contribute to the improvement of problem solving skills of the learners.

From the definition of mathematics and geometry that we mentioned about, mathematics and geometry are the main aim of the students who are part of everyday life to come from above the problems that they can meet in their lives and give them the necessary equipment to fight against these problems. The whole of mathematics rules and bases is the object of geometry and objects, but both contribute to the solution of the problems in the daily life of the main purpose students. If we can create this awareness in our students, we can help them make better sense of their own lives and make them meaningful. So they will give the best answer in order to ask why mathematics and geometry are necessary in their lives.

\subsection{Van Hiele Geometric Thinking Levels}

The most important of the studies on geometric thinking and the development of geometric thinking is a work by Pierre Marie Van Hiele and his wife Dina Van Hiele Geldof called "Van Hiele Theory". Van Hiele's theory emerged as a product of two educators completing their doctoral studies at the University of Utrecht in 1957. The theory attracted the attention of countries such as America and Russia in the 1970s, which was put forward in 1957, and has been widely used since 1984 in the world. Along with this theory, many studies on geometry and geometric thinking have been made based on this foundation [8].

The geometric thinking levels of Van Hiele's geometric thinking theory are defined by Van Hiele as 0-4 level [9]. According to Senk [10] (Transported from Ilhan, 2011), arranging the geometric levels as 1-5 will provide us with the level of " 0 " for the students who can not be assigned to visual rotation, which is the first step of geometric levels. Van Hiele levels will be considered as 1-5 in this research. For students who can not be assigned to any level, Clements and Battista (1990) [11] will use level 0, which is expressed as "semi-revitalization / pre-recognition period in the eye"

Level I (Visual Period): Visual Era Van Hiele is the first level in geometric thinking. Students at this level can learn the names of the forms and somehow recognize them as a whole [9]. Pesen stated that [12] students at this level can not comprehend geometric shapes by making use of their definitions, they are also injured, compared and named from daily life examples based on their observations in their surroundings.

The definitions of geometric objects and shapes in students at this level do not make sense for them to recognize shapes. For example: The definition of "quadrangle parallelogram with parallel sides" would not make sense to recognize the shape of a student parallelogram at this level. What is important for the student is the appearance of the shapes and the experiences of the student in daily life. If you have such an experience visually in your daily life about parallelogram, it will be easy to understand that it is parallelogram.

Level II (Analysis): Van Hiele is the second level of Van Hiele geometric thinking theory is analysis. Students at this level begin to analyze the properties of geometric objects and shapes (Crowley, 1987, Clements \& Battista, 1990) [11] and [13]. Students at this level can determine the characteristics of the shapes. For example: "The rectangles have 4 angles" [9]. A student at this level can identify with features that he / she has more than visuality and appearance [14]. Students at this level can understand that a feature also represents the class to which it belongs at the same time, so that they can fully consider the features of the forms together [15]. From here, it can generalize certain features to the whole. For example: "The diagonals of an equilateral quadrangle are perpendicular" can be generalized as "diagonals of all equilateral quadrants are perpendicular." The student experimentally explores and proves activities such as folding and measuring shapes and features of shapes [6] ve [16].

Level III (Informal Deduction): The most important feature that distinguishes this level from the visual period and analysis levels is that they begin to notice the relationships between objects and shapes. A student at this level can understand the relationships between shapes and properties of objects. Definitions, axioms are meaningful for the student but logical conclusions are not yet understood [14].

Students at this level can logically see inter-form relationships but can not work in a mathematical system. They can follow the proofs, but they can not write proofs [9]. Since students at this level can see the relationship between objects and shapes, "Each cube is a square prism at the same time. Each square prism is also a rectangular prism. In that case, the cube is the rectangle prism at the same time. "The most important feature of this level is the ability to make connections between objects and shapes.

Level IV (Formal Deduction): The most important feature that differentiates this level from other levels is that the knowledge and skills of the students come to the level of proof. Students make use of predefined axioms and theorems when doing these proofs [17]. Students at 
this level can understand the importance of proof based on postulates and theorems and they can do proofs [9]. They can use an axiomatic setup and see different applications of a theater. The properties of objects and shapes become independent objects [18]. For example: The concepts "perpendicularity", "diagonal" and "angle" in the sentence "Karen's diagonals intersect at right angles" will become independent.

Level V (Rigor): The last advanced level of geometric thinking theoryof the Van Hiele is this level. According to Hoffer [14] (Trans. Rose, 2014), students at this level are able to understand the differences between different axiomatic systems. He can also interpret the definitions, theorems, and axioms of Euclidean geometry in non-Euclidean geometries. They can understand the differences of the axiomatic systems and recognize the relationships between them. This can be seen as an area in which axiomatic systems can operate.

It is aimed to determine the Van Hiele geometric thinking levels of 8th grade students and to examine the information about geometric objects in terms of Van Hiele geometric thinking levels. The research problems of the study is that "what is the level of geometric thinking of Van Hiele on the geometric objects subject of 8th grade students and how is it? Answers of research problems was sought. Research roblems to be answered within the framework of main research problems are as follows:

1. What are Van Hiele's geometric thinking levels of 8th grade students according to the Van Hiele geometry test results?

2. Is there a significant relationship between the Van Hiele geometry test scores and the geometric objects achievement test scores of 8th grades?

3 . Is there a significant mean difference between the schools in terms of Van Hiele's geometric thinking levels?

4. Is there a significant mean difference between the schools in terms of the geometric objects achievement test?

5. Is there a significant mean difference between Van Hiele's geometric thinking levels of 8 th grade students in terms of gender?

6. Is there a significant mean difference between achievment levels at the geometric objects scores of 8th grade students in terms of gender?

\section{Method}

This study is aimed at examining the knowledge of geometric objects of 8th grade students in terms of Van Hiele's geometrical thinking levels, a survey model was used from quantitative research designs. "Survey models are research approaches aimed at describing a situation that exists in the past or present as it exists. The subject of the investigation is trying to be defined as if the individual or the object is within its own conditions.". No attempt is made to influence and change the subjects in any way ([19] p.77)

\subsection{Sample of the Study}

In this study, convenient sampling was used for non-random sampling types when selecting schools. "Appropriate sampling is due to the limitations in terms of time, money and labor, so that the sample is selected from easily accessible and practicable units" [20]. The study group consists of 61 students in Erciyes Secondary School located in the province of Melikgazi in Kayseri province, 48 students in Mehmet Tarman Secondary School in Kocasinan, and 52 students in secondary school in Nuh Mehmet Yamaner Anatolian Imam Hatip High School. A total of 161 students, 83 female and 78 male students participated in the research.

Because of the high number of classrooms in the schools, simple unselected sampling was used while selecting the classes. Classes were randomly selected and questionnaires were administered to the students in the selected classes.

\subsection{Instruments}

Van Hiele Geometry Test and Geometric Objects Achievement Test were used to collect the data of the study.

\subsection{Van Hiele Geometry Test}

Van Hiele Geometry Test developed by [9] was used to determine the geometric thinking levels of 8th grade students [21] made adaptation, validity and reliability studies of Van Hiele Geometry Test to Turkish lnguage. In this study, Cronbach Alpha reliability measures were calculated as $0.82,0.51,0.70$ for the first, second and third levels respectively [22]. The Van Hiele Geometry Test consists of 25 questions, 5 of which correspond to each level.

Van Hiele levels were used by some researchers as I-V and by some researchers as 0-IV. Using I-V allows students who can not be assigned to any level to be defined as level 0 [10]. Van Hiele levels were used as I-V in this research.

In some studies, at least 4 correcting conditions were searched for at each level, and in some studies, 3 correcting conditions were searched for in order for the students to reach a higher level. According to Usiskin [9] (transferred İlhan, 2011), the criterion to be selected differs according to the type of error to be controlled in the investigation. If the type I error (rejection while the basic hypothesis is true) is to be controlled in the research, then at least 4 of the 5 questions must be correctly answered. Otherwise, it may be the case that the individual is assigned to a level above the geometric thinking level. If it is desired to control the type II error (the basic hypothesis can not be rejected while it is wrong), it must be conditioned that at least 3 of the 5 questions are correctly answered. Having at least 3 correctly answered 5 of the questions, it can be avoided that the level of geometric thinking of the individual is lower than that level. In this study, those who answered correctly 3 or more questions to each of the 5 questions regarding the Van Hiele levels were assigned to a higher level.

If the students answer correctly 3 of the first 5 questions, the student who reaches the 1 st level (visual period) responds correctly to 3 of the second 5 questions. (analysis) is assigned. Even if a student who can not reach Level I responds correctly to 3 of the 5 problems, II. can not be assigned to level. Levels are hierarchical. The 
characteristics of Van Hiele's geometric thinking test are given in Table 1:

Table 1. Characteristics of Van Hiele Geometry Thinking Test

\begin{tabular}{|c|c|l|}
\hline Questions & Levels & \multicolumn{1}{c|}{ Features } \\
\hline $\mathbf{1 - 5}$ & 1 & $\begin{array}{l}\text { It's about visual form. It aims to determine } \\
\text { whether the students recognize the shape by } \\
\text { looking at the shape of the figure. }\end{array}$ \\
\hline $\mathbf{6 - 1 0}$ & 2 & $\begin{array}{l}\text { It is concerned with the characteristics of the } \\
\text { forms and on the one hand it aims to show that } \\
\text { the students do not know the forms and on the } \\
\text { other hand they do not know the characteristics } \\
\text { of the forms. }\end{array}$ \\
\hline $\mathbf{1 1 - 1 5}$ & 3 & $\begin{array}{l}\text { It determines whether students can recognize the } \\
\text { relationships between forms. They identify } \\
\text { students who respond correctly to questions in } \\
\text { this group and have proven that they have } \\
\text { knowledge of axioms. }\end{array}$ \\
\hline $\mathbf{1 6 - 2 0}$ & 4 & $\begin{array}{l}\text { It is the question of reasoning and logical } \\
\text { deduction. In these questions, it is determined } \\
\text { whether the students are at a level of } \\
\text { understanding and writing. }\end{array}$ \\
\hline $\mathbf{2 1 - 2 5}$ & 5 & $\begin{array}{l}\text { The questions at this level are used to determine } \\
\text { whether students can reason in Euclidean and } \\
\text { Euclidean geometries. }\end{array}$ \\
\hline
\end{tabular}

Source: Hurma, 2011, s.60

\subsection{Geometric Objects Success Test}

In order to measure the adequacy of students in terms of geometric objects, a 20-question multiple choice geometric objects achievment test was developed by the researcher. While preparing the questions, 2 expert and 3 mathematics teachers' opinions were taken and the objectives of MNE (Ministry of National Education) 2016-2017 academic year were taken into consideration. Among these learning objectives are these:

1. Identify the upright prisms and determine their basic features, elements, and draw the opening.

2. Identify the basic elements of the upright circular cylinder, build and draw the opening.

3. Identify the right pyramid, identify the basic elements, build and draw the opening.

4. Right cones diagnosis determines the basic elements, it draws the construction and developments were prepared in accordance with the gain ([3], pp. 40-41). Since the contents of the acquisitions are different, the number of questions related to acquisitions is also different. When the questions are prepared, they are prepared in a mixed way, not according to the order of acquisition.

5. Questions related to level 1 in the achievement test of geometric objects, II. 13 questions about level and III. 2 questions about the level were asked. While the achievement test of the geometric objects is being prepared, the related gains are mostly in the II. because it is related to the level II. the number of questions was too high. IV. level and V. level, the students were not questioned at these levels.

Two experts and three teachers were interviewed about the validity of the test and the interviewees indicated that the content of the test was at a level that could track achievements. The Pearson correlation coefficient between the geometric success test and the Van Hiele geometry test was calculated and the value was $0.702(\mathrm{p}=$ $0.00<0.05)$. We can say that the geometric objects prepared for this value serve the purpose of success test. On the reliability of the test, the KR-20 was calculated and the value was 0.72 . According to this value, we can say that the reliability of the test is good.

\subsection{Data Collection}

The Geometric Objects Achievement Test developed for the collection of data by the researcher and the Van Hiele Geometry Test were used. Permission to apply to schools has been obtained. For students who were selected by unselected sampling method within the scope of Acceptance Permit, students were given 35 minutes to solve the Van Hiele Geometry Test. The second lesson was given for 40 minutes to solve the Geometric Objects Achievement Test consisting of 20 questions. Tests were collected at the end of the given periods.

\subsection{Analysis}

The data obtained from the Van Hiele Geometry Test and Geometric Objects Achievement Test were analyzed using the SPSS 20 package program. Descriptive statistical analsis as average, standard deviation, frequency and percentage were run. A Pearson Correlation test was used to find the relationship between the tests [23]. In order to test the mean significant difference between the groups, the normality of the distribution was first analyzed by the Kolmogorov-Smirnov normality test from the nonparametric tests. According to the result of the Geometric Objects Achievement Test, $z=1,099$ and $p=0,178$ values were found. According to the result of Van Hiele Geometry Test, $\mathrm{z}=1.751$ and $\mathrm{p}=0.074$ values were found. The p-value is greater than 0.05 for both tests. The sampling distribution is satisfied the normallity condition. In this case, it is possible to use parametric tests. Independent Samples $t$ test and Levene's test were applied. In the case of a mean significant difference between the groups as a reuslt of ANOVA, the Scheffe test was used in the post-hoc test and the source of the difference was found.

\section{Results}

\subsection{Results of First Problem}

The first problem of the research, "What is the level of geometric thinking of Van Hiele according to the Van Hiele Geometry Test results of the 8th grade students?". The results are given in Table 2, Table 3, Table 4, Table 5 as schools and study group.

Table 2. Mehmet Tarman Middle School Van Hiele Geometry thinking levels

\begin{tabular}{|c|c|c|}
\hline $\begin{array}{c}\text { Van Hiele Geometry Thinking } \\
\text { Levels }\end{array}$ & $\begin{array}{c}\text { Frequency } \\
\text { (f) }\end{array}$ & $\begin{array}{c}\text { Percentage } \\
(\mathbf{\%})\end{array}$ \\
\hline Level 0 (semi-visualization) & 8 & 16.7 \\
\hline Level I (Visual Semester) & 32 & 66.6 \\
\hline Level II (Analysis) & 6 & 12.5 \\
\hline Level III (Lifelong Extraction) & 2 & 4.2 \\
\hline Level IV (Conclusion) & 0 & 0 \\
\hline Level V (Most Advanced Period) & 0 & 0 \\
\hline Total & 48 & 100 \\
\hline
\end{tabular}


When Table 2 was examined, 8 of the students in Mehmet Tarman middle school were at level 0 . No students reached level IV and level V. At the highest rate of $66.6 \%, 32$ persons were staying in level I while 6 people were in level II. At the highest level, level III, only 2 students were able to reach. As a result, most of the students in Mehmet Tarman Middle School are in the visual period at the level of Van Hiele Geometry Test.

Table 3. N. M. Yamaner Anatolian Imam Hatip High School Van Hiele Geometry Thinking Levels

\begin{tabular}{|c|c|c|}
\hline $\begin{array}{c}\text { Van Hiele Geometry Thinking } \\
\text { Levels }\end{array}$ & $\begin{array}{c}\text { Frequency } \\
\text { (f) }\end{array}$ & $\begin{array}{c}\text { Percentage } \\
\text { (\%) }\end{array}$ \\
\hline Level 0 (semi-visualization) & 7 & 13.5 \\
\hline Level I (Visual Semester) & 35 & 67.3 \\
\hline Level II (Analysis) & 10 & 19.2 \\
\hline Level III (Lifelong Extraction) & 0 & 0 \\
\hline Level IV (Conclusion) & 0 & 0 \\
\hline Level V (Most Advanced Period) & 0 & 0 \\
\hline Total & 52 & 100 \\
\hline
\end{tabular}

In Table 3, 67.3\% (35 people) of the 8th grade students in secondary school in Nuh Mehmet Yamaner Anatolian Imam Hatip High School are in the visual period. 7 students stayed at level 0 , while 10 students reached the level of analysis. None of the students reached level III, level IV, and level V. As a result, most of the 8th grade students in secondary school in the Anatolian Imam Hatip High School of Nuh Mehmet Yamaner are in the visual period at the level of Van Hiele Geometry Test

Table 4. Erciyes Secondary School Van Hiele Geometry Thinking Levels

\begin{tabular}{|c|c|c|}
\hline $\begin{array}{c}\text { Van Hiele Geometry Thinking } \\
\text { Levels }\end{array}$ & $\begin{array}{c}\text { Frequency } \\
\text { (f) }\end{array}$ & $\begin{array}{c}\text { Percentage } \\
\text { (\%) }\end{array}$ \\
\hline Level 0 (semi-visualization) & 2 & 3.3 \\
\hline Level I (Visual Semester) & 38 & 62.3 \\
\hline Level II (Analysis) & 17 & 27.9 \\
\hline Level III (Lifelong Extraction) & 4 & 6.5 \\
\hline Level IV (Conclusion) & 0 & 0 \\
\hline Level V (Most Advanced Period) & 0 & 0 \\
\hline Total & 61 & 100 \\
\hline
\end{tabular}

In Table $4,62.3 \%$ of the students in Erciyes Middle School is at level I. 2 students sare at level 0, 17 students were level II and 4 students are level III. In Erciyes Middle School, the none of the students reach level IV and level V. As a result, most of the students in Erciyes Middle School remained in the visual period.

Table 5. Van Hiele Geometric Thinking Levels

\begin{tabular}{|c|c|c|}
\hline $\begin{array}{c}\text { Van Hiele Geometry Thinking } \\
\text { Levels }\end{array}$ & $\begin{array}{c}\text { Frequency } \\
\text { (f) }\end{array}$ & $\begin{array}{c}\text { Percentage } \\
(\mathbf{\%})\end{array}$ \\
\hline Level 0 (semi-visualization) & 17 & 10,5 \\
\hline Level I (Visual Semester) & 105 & 65,2 \\
\hline Level II (Analysis) & 33 & 20,5 \\
\hline Level III (Lifelong Extraction) & 6 & 3,8 \\
\hline Level IV (Conclusion) & 0 & 0 \\
\hline Level V (Most Advanced Period) & 0 & 0 \\
\hline Total & 161 & 100 \\
\hline
\end{tabular}

In Table 5, only 6 out of 161 students in sample were able to reach level III. While 17 students were at level 0 , 105 students reached to level I and 33 students reached to level II. None of the students in sample were at levels IV and $\mathrm{V}$. When percentages are examined, $65.2 \%$ of the students in sample were at the level of I. According to the results, it can be said that 8 th grade students' Van Hiele geometry thinking levels are below of th expected level.

\subsection{Results of Second Problem}

The second problem of the research is "Is there a meaningful relationship between the grades of the students in the Van Hiele Geometry Test and the Geometric Objects Achievement Test?". The Pearson correlation test was applied to Van Hiele Geometry Test and Geometric Objects Achievement Test to answer the second problem.

The relationship between the Geometry Objects Achievement Test and Van Hiele Geometry Test scores was 0.702 according to Pearson correlation coefficient. There is a high positive correlation between the students' scores obtained from the Van Hiele Geometry Test and Geometric Objects Achievement Test.

\subsection{Results of Third Problem}

The third problem of the research is "Is there a statistically mean difference between the schools in terms of Van Hiele's Geometric Thinking Levels?" For this problem, firstly the maximum and minimum numbers and arithmetic averages of Van Hiele Geometry Test of 3 different schools were found. The results are given in Table 6.

Table 6. Schools' Descriptive Statistics of Van Hiele Geometry Test

\begin{tabular}{|c|c|c|c|c|c|c|}
\hline Schools & $\mathbf{n}$ & $\mathbf{X}$ & $\mathbf{S S}$ & $\begin{array}{c}\text { Standard } \\
\text { error }\end{array}$ & $\begin{array}{c}\text { Minimum } \\
\text { Right } \\
\text { Number }\end{array}$ & $\begin{array}{c}\text { Maximum } \\
\text { Right } \\
\text { Number }\end{array}$ \\
\hline M. Tarman & 48 & 8.22 & 2.72 & 0.39 & 3 & 15 \\
\hline N.M.Yamaner & 52 & 6.61 & 1.71 & 0.23 & 3 & 11 \\
\hline Erciyes & 61 & 9.36 & 2.90 & 0.37 & 3 & 15 \\
\hline Total & 161 & 8.13 & 2.76 & 0.21 & 3 & 15 \\
\hline
\end{tabular}

When Table 6 is analyzed, the mean of the correct answers given by M. Tarman Middle School students to the Van Hiele Geometry Test is approximately 8.2, the mean of N. M. Yamaner İmam Hatip High School students is approximately 6.6 and the mean of Erciyes Middle School students' is approximately 9.3. The lowest correct answer number given to the Van Hiele Geometry Test at 3 separate schools is 3 . The highest number of answers given to the Van Hiele Geometry Test is 15 for $\mathrm{M}$. Tarman and Erciyes Middle Schools, while 11 for N. M. Yamaner Imam Hatip High School, The Levene's test result is given in Table 7 to measure the homogeneous distribution of variances.

Table 7. Levene's test results of schools according to Van Hiele Geometry Test

\begin{tabular}{|c|c|c|c|}
\hline Levene & df1 & df2 & p \\
\hline 1.762 & 2 & 158 & 0,102 \\
\hline
\end{tabular}

According to Levene's test result given in Table 7, the variances are homogeneously distributed $(\mathrm{p}=0,102>$ $0,05)$. The One Way ANOVA test was used to determine whether there was significant mean difference in Van Hiele levels between schools. The results are given in Table 8. 
Table 8. Anova results between schools in terms of Van Hiele Levels

\begin{tabular}{|c|c|c|c|c|c|}
\hline Anova & SS & df & Sum of squares & F & p \\
\hline Between groups & 212.1 & 2 & 106.0 & 16.64 & 0.00 \\
\hline In-group & 1006.8 & 158 & 6.3 & & \\
\hline Total & 1218.9 & 160 & & & \\
\hline
\end{tabular}

There is a significant mean difference in Van Hiele levels among schools $(\mathrm{F}(2,158)=16.64, \mathrm{p}=0.000$ $<0.05)$. There was a significant mean difference between the schools in the ANOVA results. In this case, the Scheffe test was used as a post-hoc test to determine school differentiation.

According to the Scheffe test results to the Van Hiele Geometry Test, there was a significant mean difference between Mehmet Tarman and Nuh Mehmet Yamaner Anatolian Imam Hatip High School in favor of Mehmet Tarman Middle School $(\mathrm{p}=0.007<0.05)$. There was no significant mean difference between Mehmet Tarman Middle School and Erciyes Middle School $(p=0.07>$ 0.05). A significant mean difference was found between Erciyes Middle School and Nuh Mehmet Yamaner Anatolian Imam Hatip High School in favor of Erciyes Middle School $(p=0.000<0.05)$.

\subsection{Results of Fourth Problem}

The fourth problem of the study is "Is there a significant mean difference between schools in terms of Geometric Objects Achievement Test?" For this problem, firstly, maximum and minimum correct numbers and mean of the students of 3 schools on the Geometric Objects Achievement Test were found. The findings was given in Table 9.

Table 9. Descriptive Statistics of schools in Geometrical Objects Achievement Test

\begin{tabular}{|c|c|c|c|c|c|c|}
\hline & $\mathbf{n}$ & $\mathbf{X}$ & $\mathbf{S S}$ & $\begin{array}{c}\text { Standard } \\
\text { error }\end{array}$ & $\begin{array}{c}\text { Minimum } \\
\text { Score }\end{array}$ & $\begin{array}{c}\text { Minimum } \\
\text { Score }\end{array}$ \\
\hline M. Tarman & 48 & 11.9 & 3.1 & 0.4 & 4 & 19 \\
\hline N.M.Yamaner & 52 & 10.5 & 2.6 & 0.3 & 5 & 17 \\
\hline Erciyes & 61 & 13.7 & 3.4 & 0.4 & 5 & 19 \\
\hline Total & 161 & 12.1 & 3.3 & 0.2 & 4 & 19 \\
\hline
\end{tabular}

In Table 9, the mean of the answers given by $\mathrm{M}$. Tarman Middle School students to the Geometric Objects Achievement Test is approximately 11.9. N. M. Yamaner Imam Hatip High School mean of the students is about 10.5 and the arithmetic average of the students in Erciyes Middle School is about 13.7. The lowest correct answer number given to the Geometric Objects Achievement Test is 4 for M. Tarman Middle School and is 5 for N. M. Yamaner Imam Hatip High School and Erciyes Middle School. The highest number of correct answers given to the Ggeometric Objects Achievement Test is 19 for Erciyes and M. Tarman Middle Schools and 17 for N. M. Yamaner Imam Hatip High School.

Levene's test was applied to measure the homogeneous distribution of variance. The Levene's test result is given in Table 10.

Table 10. Levene's test results of Geometric Objects Achievement Test

\begin{tabular}{|c|c|c|c|}
\hline Levene Statistic & df1 & df2 & p \\
\hline 2.863 & 2 & 158 & 0.060 \\
\hline
\end{tabular}

According to Levene's test result given in Table 10, the variances are homogeneously distributed $(p=0.06>0.05)$.

One-way ANOVA was used to determine whether there was a significant mean difference between the schools in terms of Geometric Objects Achievement Test. The results are given in Table 11.

Table 11. Anova Results of the Geometric Objects Achievement Test

\begin{tabular}{|c|c|c|c|c|c|}
\hline & $\begin{array}{c}\text { Sum of } \\
\text { squares }\end{array}$ & df & $\begin{array}{c}\text { Sum of } \\
\text { squares }\end{array}$ & $\mathbf{F}$ & $\mathbf{p}$ \\
\hline $\begin{array}{c}\text { Between } \\
\text { groups }\end{array}$ & 290.0 & 2 & 145.0 & 15.19 & 0.00 \\
\hline In-group & 1507.7 & 158 & 9.5 & & \\
\hline Total & 1797.7 & 160 & & & \\
\hline
\end{tabular}

In Table 11, there is a significant mean difference between the schools in terms of Geometric Objects Achievement Test $(\mathrm{F}(2,158)=15.19, \mathrm{p}=0.000<0.05)$. In this case, the Scheffe test was used as the post-hoc test to determine school differentiation. Scheffe test results showed that Geometric Objects Achievement Test is no significant mean difference between Mehmet Tarman Middle School and Nuh Mehmet Yamaner Anatolian Imam Hatip High School $(p=0.06>0.05)$. A significant mean difference was found between Mehmet Tarman Middle School and Erciyes Middle School in favor of Erciyes Middle School. $(p=0.01<0.05)$. A significant mean difference was found between Erciyes Middle School and Nuh Mehmet Yamaner Anatolian Imam Hatip High School in favor of Erciyes Middle School $(p=0.000$ $<0.05)$.

\subsection{Results of Fifth Problem}

The fifth problem of the research is "Is there a significant mean difference between Van Hiele's geometric thinking levels of 8th grade boys and girls?" Van Hiele's geometric thinking levels of boy and girl students were given in Table 12.

Table 12. Van Hiele geometric thinking levels of girl and boy students

\begin{tabular}{|c|c|c|}
\hline Van Hiele Levels & Girl & Boy \\
\hline Level 0 (semi-visualization) & 7 & 9 \\
\hline Level I (Visual Semester) & 49 & 57 \\
\hline Level II (Analysis) & 24 & 9 \\
\hline Level III (Lifelong Extraction) & 3 & 3 \\
\hline Total & 83 & 78 \\
\hline
\end{tabular}

In Table 12, 7 of the students are at level 0, 49 are level I, 24 are level II and 3 are level III. Nine of the boy students are at level 0,57 at level I, 9 at level II and 3 at level III. Independent samples $t$ test were run whether there was a significant mean difference between boy and girl students' levels of Van Hiele's geometric thinking. The results are given in Table 13.

Table 13. Independent Samples $t$ test results on Van Hiele geometry test of boy and girl students

\begin{tabular}{|c|c|c|c|c|c|c|c|}
\hline & Gender & $\mathbf{n}$ & $\mathbf{X}$ & $\mathbf{S S}$ & $\begin{array}{c}\text { Standard } \\
\text { Error } \\
\text { Rate }\end{array}$ & $\mathbf{t}$ & $\mathbf{p}$ \\
\hline $\begin{array}{c}\text { Van Hiele } \\
\text { Geometry } \\
\text { Test Total } \\
\text { Points }\end{array}$ & Girl & 83 & 8.67 & 2.67 & 0.29 & & \\
\cline { 2 - 7 } & Boy & 78 & 7.56 & 2.75 & 0.31 & 2.59 & 0.01 \\
\hline
\end{tabular}


In Table 13, the mean of the Van Hiele Geometry Test of girl students is 8.67 and the average of the Van Hiele Geometry Test of boys is 7.56. A significant mean difference was found in favor of girls according to Independent Samples $t$ Test obtained from Van Hiele Geometry Test of boys and girls $(p=0.01<0.05)$.

\subsection{Results of Sixth Problem}

The sixth problem of the research is "Is there a significant mean difference between boys and girls Geometric Objects Achievement Tests?" The answers of the boys and girls to the Geometric Objects Achievement Test were analyzed by using Independent Samples $t$ test. The results are given in Table 14.

Table 14. Independent Samples $t$ test results on boys and girls Geometric Objects Achievement Test

\begin{tabular}{|c|c|c|c|c|c|c|c|}
\hline & Gender & $\mathbf{n}$ & $\mathbf{X}$ & $\mathbf{S S}$ & $\begin{array}{c}\text { Standard } \\
\text { Error } \\
\text { Rate }\end{array}$ & $\mathbf{t}$ & $\mathbf{p}$ \\
\hline $\begin{array}{c}\text { Geometric } \\
\text { Objects } \\
\text { Achievement } \\
\text { Test Total } \\
\text { Score }\end{array}$ & Girl & 83 & 13.06 & 3.46 & 0.37 & & 0.000 \\
\cline { 2 - 8 } & Boy & 78 & 11.24 & 2.97 & 0.33 & 3.56 & 0.00 \\
\hline
\end{tabular}

In Table 14, the mean of the girls to the Geometric Objects Achievement Test is 13 and the boys are 11.2. A significant mean difference was found in favor of girls according to Independent Samples $t$ test result obtained from the Geometric Objects Achievement Test of boys and girls $(p=0.00<0.05)$. In addition, the mean of the responses of boys to the geometric objects achievement test is approximately 12.1 in 20 questions. This is approximately $60 \%$ of the test.

\section{Discussion and Conclusion}

Van Hiele's geometric thinking levels were lower than expected in the first problem of the research. When the MoNE achievements related to the research are examined in terms of Van Hiele steps III. the number of students reached to the level is expected to be higher. there are only 6 students (3.8\%). $33(20 \%)$ of the students participated in the research II. $105(65 \%)$ persons are at the first level and $17(11 \%)$ persons are at the 0th level. In this direction, most of the students are in the first level. Considering the achievements of the 8th grade geometry, it is difficult for the students at the first level to understand these achievements. $17(11 \%)$ students are at level 0 . The level of Van Hiele levels is expected to be higher than ninth grade primary school students [24] and [4]. Students at this level are thought to be difficult to achieve in the 8th grade geometry gains.

Gül [25] researched with the 134 students who participated in the research on the triangles with 8th grade students, 13 (9.7\%) were at III Van Hiele level respectively. However, $9(6.7 \%)$ were unable to reach any level and stayed at level 0 . Van Hiele's geometric thinking levels of 8th grade students were found to be lower than expected. In this study, Van Hiele's thinking levels are parallel to the results obtained in the study.
Şahin [26] is studying with classroom teachers and classroom teacher candidates, while İlhan [12] is studying with mathematics teacher candidates, she is studying with [27] middle school students; Van Hiele's geometric thinking levels of students, prospective teachers and teachers were found to be low. Van Hiele's thinking levels in this study are in parallel with the results obtained in the studies mentioned.

Moreover, according to [9], most of the students in America have Van Hiele geometry thinking levels I and II. It is level and should be low. The result obtained in this study is in parallel with the result obtained from [9].

The Pearson correlation coefficient of the Van Hiele Geometry Test and Geometric Objects Achievement Test prepared by the researcher with the expert opinion, the teacher opinion and the 8 th class achievements was found to be 0,702 in order to collect the data of the research on the second problem of the research. It was found that there is a high correlation between the Geometric Object Achievement Test and the Van Hiele Geometry Test in the positive direction. According to this result, it can be said that the students who have high level of Van Hiele are high in the success of the geometric objects achiement test, and the student of the low level of Van Hiele is low in the success of the geometric objects.

In the findings of the third problem of the study, the mean of the answers given by the students to the Van Hiele geometry test was 8.1. According to these results, the mean of the students in M. Tarman Secondary School was found to be 8.2, N. M. Yamaner Imam Hatip High School 6.6 and Erciyes Middle School 9.3.

In the study, Erciyes Middle School became the most successful school in the average of correct answers in Van Hiele geometry test and geometric objects achievment test. These differences can be attributed to many factors, such as the environment in which the school is located, the structure of the school, school equipment, school teachers, the environment in which the students live, and the cultural and economic structure of their families.

In the fifth problem of the research, Van Hiele's Geometry Test was investigated in terms of gender. According to the results, $8 \%(\mathrm{n}=7)$ of the girl students had level 0, 59\% $(\mathrm{n}=49)$ level I, 29\% $(\mathrm{n}=24)$ level II and $4 \%$ level III. $12 \%(\mathrm{n}=9)$ of the boy students were at level $0,73 \%(n=57)$ level I, $12 \%(n=9)$ level II and $4 \%$. When the levels of boy and girl students were examined, according to the results, there is significant mean difference between boy and girl students. It can be said that the number of students at the level is influential.These results are in parallel with the studies [28], [22] and [29].

Şahin [26] has been working with classroom teachers and classroom teacher candidates. While there was a significant gender difference in the level of geometric thinking of the Van Hiele classroom teachers, there was a significant mean difference in the classroom teacher candidates towards the boys. In addition, there were no significant mean differences in Van Hiele geometric thinking levels when studies in the literature revealed that [12,26,30,31].

In the sixth problem of the study, the investigation of the geometric objects achievement test in terms of gender variation was searched. According to the results, the mean of the answers given by the boy students to the 
geometrical objects achievment test is approximately 11.2 while the mean of the girl students is 13. On average, girls are more successful than boys in geometric objects achievement test. Independent samples t test was used to see if there was a significant mean difference between boy and girl students. According to the results, there was a significant mean difference in favor of girl students in the geometric objects achievement test $(p=0.000<0.05)$.

In the other finding related to the sixth problem, mean of geometric objects achievement test of 161 students was found to be about 12.1 in 20 questions. This is equivalent to $60 \%$ of the questions. This average was lower than expected.

\section{References}

[1] Alkan, H. ve Altun, M. (1998). Matematik öğretimi, Açıöğretim Fakültesi Yayınları, Eskişehir.

[2] Baykul, Y. (1994). "Illköğretim Okullarında Matematik Öğretimine Bakış", İlköğretim okullarında matematik öğretimi ve sorunları, Türk Eğitim Derneği Yayınları, Ankara.

[3] Milli Eğitim Bakanlığı (2013). Ortaokul matematik dersi (5, 6, 7, 8.sınıflar) öğretim programı, Ankara.

[4] NTCM, (2000), Curriculum and Evaluation Standarts for School Mathematics, Online.

[5] Pesen, C. (2003). Eğitim fakülteleri ve sinıf öğretmenleri için matematik ögretimi. (1.Baskı). Ankara: Nobel Yayın Dağıtım.

[6] Olkun,Sinan ve Tuba Aydoğdu. "Üçüncü Uluslararası Matematik ve Fen Araştırması (TIMSS) Nedir? Neyi Sorgular? Örnek Geometri Soruları ve Etkinlikler", 2003. İnternet Adresi: http//www.ilkogretim-online.org/vol2_say11, Erişim Tarihi: 21.02.2003.

[7] Baki, A. (2001). Bilişim teknolojisi 1şı̆̆ı altında matematik eğitiminin değerlendirilmesi, Milli Eğitim Dergisi, 149, 26-31.

[8] Olkun, S. ve Toluk, Z. (2003). Matematik ögretimi. Ankara: Anı Yayıncilik.

[9] Usiskin, Z. (1982). Van Hiele Levels and Achievement in Secondary School Geometry, University of Chicago, ERIC Document Reproduction Service.

[10] Senk, S. L. (1989). Van Hiele Levels and Achievement in Writing Geometry Proofs. Journal for Research in Mathematics Education, 20(3), 309-321.

[11] Clements, D. H. Battista, M. T. (1990). The Effects of Logo on Childrens' Conceptuazilations of Angle and Polyongs. Journal For Research in Mathematics Education, 21(5), 356-371.

[12] İlhan, M. (2011). Illköğretim ve ortaöğretim matematik öğretmen adaylarının geometrik düşünme düzeylerinin çeşitli değişkenler açısından incelenmesi, Yüksek lisans tezi, Dicle Üniversitesi, Diyarbakır.

[13] Crowley, M. L. (1987). The Van Hiele Model of the Development of Geometric Thought. In M.M. Lindquist, Ed., Learning and Teaching Geometry, K-12 (1-16).

[14] Hoffer, A. (1981). Geometry is more than proof. Mathematics Teacher, 74, 11-18.

[15] Baykul, Y. (2009). Illköğretimde matematik ögretimi: 6-8. Sintflar (1.Baskı). Ankara: PegemA Yayıncılık.
[16] Koçak, B, B. (2009). Süsleme etkinliklerinin ilköğretim 5.slnıf ögrencilerinin Van Hiele geometrik düșünme düzeylerine etkisi, Yüksek lisans tezi, Osmangazi Üniversitesi, Eskişehir.

[17] Olkun, S. ve Toluk Uçar, Z. (2007). Ilköğretimde etkinlik temelli matematik ögretimi, Ankara: Maya Akademi.

[18] Altun, M. (2008). Matematik öğretimi (1. Baskı). Bursa: Aktüel Alfa Akademi.

[19] Karasar, N. (2007). Bilimsel Araştırma Yöntemi (17.Bask1). Ankara: Nobel Yayın Dağıtım.

[20] Büyüköztürk Şener, Doç. Dr. Şener Büyüköztürk, http://w3.balikesir.edu.tr/ msackes/wp/wpcontent/uploads/2012/03/BAY-Final-Konulari.pdf, (SGT: 15.07.2017).

[21] Duatepe, A. (2000). An Investigation of The Relationship Between Van Hiele Geometric Level of Thinking and Demographic Variable for Pre-Service Elementary School Teacher. Yayımlanmamış Yüksek Lisans Tezi, Ortadoğu Teknik Üniversitesi, Ankara.

[22] Duatepe, A. (2004). The effects of drama based instruction on seventh grade students' geometry achievement, Van Hiele geometric thinking levels, attitude toward mathematics and geometry. Doktora Tezi, Orta Doğu Teknik Üniversitesi Fen Bilimleri Enstitüsü, Ankara.

[23] Büyüköztürk Ş., Çokluk Ö., Köklü N. (2013). Sosyal Bilimler için İstatistik (12. Bask1). Ankara: PegemA Yayınc1lık.

[24] Altun, M., (2005), Matematik Öğretimi, Bursa: Alfa Akademi Basın Dağıtım.

[25] Gül, B. (2014). Ortaokul 8.sınıf ögrrencilerinin üçgenler konusundaki matematik basarllarl ile Van Hiele geometri düşünme düzeyleri iliş̧kisinin incelenmesi, Yüksek lisans tezi, Gazi Üniversitesi, Ankara.

[26] Şahin, O. (2008), Sınıf Öğretmeni ve Sınıf Öğretmeni Adaylarının Van Hiele Geometrik Düşünme Düzeyleri, Yüksek Lisans Tezi, Afyon Kocatepe Üniversitesi, Afyonkarahisar.

[27] Coşkun, F. (2009). Ortaögretim öğrencilerinin Van Hiele geometri anlama seviyeleri ile ispat yazma becerilerinin ilişkisi, Yüksek lisans tezi, Karadeniz Teknik Üniversitesi, Trabzon.

[28] Aksu, H, H. (2010). Öğretmen Adayları Niteliklerinin Van Hiele Geometrik Düşünme Düzeyine Uygunluğunun Değerlendirilmesi. IX. Ulusal Fen Bilimleri ve Matematik Eğitimi Kongresi. (23-25 Eylül 2010). İzmir: Dokuz Eylül Üniversitesi.

[29] Olkun, S.; Toluk, Z.; Durmuş, S. (2002). Matematik ve Sınıf Öğretmenliği Birinci Sınıf Öğrencilerinin Geometrik Düşünme Düzeyleri. V. Ulusal Fen Bilimleri ve Matematik Eğitimi Kongresi. (16-18 Eylül 2002). Ankara: Ortadoğu Teknik Üniversitesi Kültür ve Kongre Merkezi.

[30] Halat, E. (2006). Sex-related Differences in the Acquisition of the Van Hiele Levels and motivation in learning geometry. Asia Pacific Education Review, 7 (2), 173-183.

[31] Oflaz, G. (2010). Geometrik düşünme seviyeleri ve zekâ alanlar arasindaki ilişki. Yüksek lisans tezi, Cumhuriyet Üniversitesi, Sivas.

[32] Altun, M. (2005). İlköğretim ikinci kademede matematik öğretimi (4.Baskı). Bursa: Alfa Basım Yayım.

[33] Altun, M. (2008). Eğitim fakülteleri ve sinıf öğretmenleri için matematik öğretimi (14.Baskı). Bursa: Alfa Basım Yayım.

[34] Reston, VA: National Council of Teachers of Mathematics.

[35] Hurma, A.R. (2011). 8. sınıf geometri dersi çokgenler açı ünitesinde Van Hiele modeline dayal ögretimin öğrencinin problem çözme başarısina ve ögrenmenin kalıcllğına etkisi, Yüksek lisans tezi, Atatürk Üniversitesi, Erzurum. 